\title{
The Development of Mathematics and Soft Skills at the Graduate Level through Project- Based Learning in Times of COVID-19
}

\author{
Edgar O. Cardoso-Espinosa ${ }^{1}$, Jésica A. Cortés-Ruiz ${ }^{2}$, Ma. Elena Zepeda-Hurtado ${ }^{3}$ \\ ${ }^{1}$ Instituto Politécnico Nacional (IPN) ESCA-ST, Mexico City, Mexico \\ ${ }^{2}$ Instituto Politécnico Nacional (IPN) CIECAS, Mexico City, Mexico \\ ${ }^{3}$ Instituto Politécnico Nacional (IPN) CECyT 11, MexicoCity, Mexico
}

\begin{abstract}
The objective of the research was to analyse the development of mathematical competences and soft skills in graduate students through the implementation of the Project-Based Learning methodology in times of COVID-19. The type of study used was a quantitative methodology with a descriptive scope. The instrument used to obtain the information was a questionnaire based on a five-point Likert scale. The main results were that the participants developed the mathematical competences of using mathematical terminology, formulating and estimating the quantitative model. The soft skills developed were time management, collaborative work, self-regulation and decision-making.
\end{abstract}

Keywords - Project-Based Learning, mathematical competences, soft skills, graduate, COVID-19

\section{Introduction}

Given the emergence of the COVID-19 pandemic, the incidence of information and communication technologies (ICT) has promoted an evolution of training processes at the international level [1], [2], [3].

DOI: $10.18421 /$ TEM104-20

https://doi.org/10.18421/TEM104-20

Corresponding author: Edgar O. Cardoso-Espinosa, Instituto Politécnico Nacional - ESCA ST, México.

Email: eoce@hotmail.com

Received: 20 August 2021.

Revised: 29 September 2021.

Accepted: 07 October 2021.

Published: 26 November 2021.

(cc) BY-NC-ND (C) 2021 Edgar O. Cardoso-Espinosa, Jésica A. Cortés-Ruiz \& Ma. Elena Zepeda-Hurtado; published by UIKTEN. This work is licensed under the Creative Commons Attribution-NonCommercial-NoDerivs 4.0 License.

The article is published with Open Access at www.temjournal.com
The ICT have allowed teachers to design and implement new didactic methodologies focused on the active training of students [4]. Therefore, the intensive use of the ICT has made it possible for the generation of knowledge to be so obsolete that the human capital needs to be continuously updated to respond to an environment in which the only permanent thing is change [5]. Hence, soft and technical skills have become fundamental pillars of professional training because they positively influence the development of organizations [6], [7]. The relevance, then, is to merge in the educational processes the training of soft and technical skills with a comprehensive approach that allow the graduates to successfully insert themselves into the labour market [8].

The Organization for Economic Cooperation and Development (OECD) [9] indicates that to achieve individual well-being and the economic success of a country, it is necessary to develop competences. Education contributes to providing a diversity of skills that allow people to face the problems and challenges of their personal and work life. Cognitive or technical skills such as reading, math, and science enable individuals to understand information, make decisions, and solve problems. Soft skills help people to establish positive relationships with others, emotional stability, self-knowledge and perseverance in difficult situations. The World Economic Forum (WEF) [10] establishes that as technology is adopted in various organizations, various relevant skills are required that human capital will have to possess: critical thinking, active learning, solving complex problems, analysis, creativity, initiative, leadership, resilience, tolerance, flexibility, reasoning, as well as the design, use, programming and control of the various technological tools.

The relevance of technological means is to allow people to actively develop their skills for both their personal and work life, which is why a professional training process that allows linking the interests and requirements of the work environment with the education provided is required [11]. Rego-Agraso [12] indicates that the relevance of professional 
training is the generation of specialized human capital in the different professional sectors that satisfies current and future job demands in a work context.

For the achievement of a comprehensive professional training provided to graduate students, there are two important components: 1) Mathematical competences because they are considered as the fundamental axis of complex knowledge processes since it uses critical, reflective and analytical thinking. Its importance lies in developing the capacities to reason, formulate and solve problems in different contexts based on specific terminology and conventional procedures [13] and 2) Soft skills, which are oriented towards proactivity, emotional intelligence, cooperation, empathy, critical thinking and decision making [14], [15]. Its relevance is to enable a better job performance of the person and even have an equal or more important effect for the positioning of human capital in organizations [16]. Consequently, a mathematical training allows human capital to have a set of tools oriented towards the analysis, measurement and action proposals for the resolution of situations in various areas of an organization [17]. Meanwhile, the training of soft skills enables human talent to adjust socially both to relationships and to adaptation to a work context [18].

Due to the sudden and widespread establishment of emergency remote teaching as a consequence of the COVID-19 pandemic, the need arose to carry out research considering the circumstance of remoteness, so the results will allow a change and educational improvement in the programs of professional training, especially in those that have only been taught in the face-to-face modality [19], [20]. Also, during confinement, Díaz-Barriga and Barrón [21] report that students who have managed to continue their academic training have manifested insignificant learning experiences, an excess of tasks, repetitive activities and an absence of teacher mediation. Meanwhile, Sánchez et al. [22] indicate that there is no research on student learning experiences at the graduate level, so it is an important topic because it addresses professional training.

Thus, the moment of crisis caused by the coronavirus must be conceived as an opportunity for the construction of new educational environments for graduate studies in order to promote disruptive innovation in educational practices that allow transition between the face-to-face, the hybrid and the virtual to achieve a quality academic training in the student body [23]. Once the confinement is concluded, the training strategies used in virtual form will constitute important advances and achievements that will have to be incorporated into the various educational programs taught by educational organizations. In addition, according to the health authorities of the countries, they have indicated that the return to the classrooms will be progressive, so that a hybrid model will continue with the academic training of students [24]. The importance of research for the graduate level is to provide useful information on the academic training of students because before the appearance of COVID-19 they were taught in a face-to-face modality which characteristics of both teaching and learning are different from a distance learning. So, the results obtained will be relevant for the formulation of training strategies for a hybrid model. In consequence, it is important that the education that is imparted is of quality, so in the context of virtuality it is the one that is achieved when the training model is articulated in a coherent way with the appropriate use of methodologies, technological tools and instruments, just as in the face-to-face model [25].

Based on the above, the general objective was to analyse the development of mathematical competences and soft skills in graduate students through the implementation of the Project-Based Learning (PBL) methodology in times of COVID-19.

\section{Literature Review}

Rodríguez, Vargas and Luna [26] establish that, at the graduate level, to achieve quality learning of scientific concepts, the use of active methodologies is required. Alptekin, Deturris and Macy [27] indicate that in graduate school, students learn from real situations so that they are relevant and useful and allow them to position them in their job performance. The main active methodologies used by teachers as well as various investigations on their effectiveness have been carried out on students during the training process in order to generate quality learning [28], [29], [30]. However, [31] point out that specific studies are required at the graduate level to determine their impact on the academic training of students in the various subjects taught.

This research considers the effectiveness of PBL at the graduate level during the COVID-19 pandemic. According to [32], [33] the PBL is a methodology focused on the student body that promotes not only the acquisition of disciplinary knowledge but also transversal competences such as communication, teamwork, problem solving, autonomy and responsibility. Therefore, the PBL enables students to develop various professional competences by linking education with work [34]. In the same way, the work of the students is autonomous, inquiring into various sources of information during the stages of the project in an inclusive, oriented and formative learning context because the teachers assume the role of mediator and guide [35], [36]. The PBL encourages the research process by carrying out a project based on a real case that enables the 
application of theory with practice, which generates not only intellectual but also social development that will allow better professional training [37].

The main characteristics of PBL according to [38] are: 1) Focusing on the substantial elements of the subject; 2) The selection of a subject that can be developed through a project; 3) The subject to be addressed has to be a challenge related to a real problem and, 4) During the project, the students have to progress not only cognitively but also in their autonomy and responsibility and even in the opening to work with others.

Hernández et al. [39] found that PBL is an adequate methodology for learning curricular content from real situations because it promotes formal thinking (organize, analyse, synthesize and conclude) as well as the project encourages the exchange of ideas among students. Mateos et al. [34] determined that PBL has a positive effect on student academic performance because $88 \%$ recognized that it promotes the development of professional skills; $80 \%$ encourages teamwork, leadership, planning and organization, and communication; $75 \%$ allows research and consultation of bibliographic information sources and $70 \%$ promotes critical thinking. These authors conclude that PBL has an impact on students due to the fact that it encourages motivation and responsibility because it links the project with professional training.

Sakulviriyakitkul, Sintanakul and Srisomphan [40] found that PBL promotes teamwork in students as well as generates high levels of motivation and interest that encourage the exchange of information for the realization of the project. In addition, they conclude that ICT contribute to supporting the effectiveness of the PBL due to the use of networks and resources that benefit learning. González, Ferreira and Barranco [41] found that PBL manages the systematization of the information to develop the product. Also, the participants indicated that they achieved more in the subject than was initially expected in regard to the use of the project associated with a problem because it generated greater interest and responsibility.

\section{Materials and Methods}

The study methodology is presented in five stages: The first is the type of research; the second describes the participants with their main sociodemographic characteristics; the third indicates the didactic intervention of the PBL; the fourth, the instrument used and the fifth the procedure and data analysis.

\subsection{Type of Research}

The research has followed a quantitative methodology with a descriptive scope because it focused on assessing the effectiveness of PBL in the development of competences at the graduate level [42]. Based on the specific characteristics of the phenomenon of the COVID-19 pandemic, a case study was carried out for a graduate degree in administration taught by the Instituto Politécnico Nacional in order to collect information because the topic addressed has a validity and relevance which findings will be useful for future research [43].

\subsection{Participants}

The participants of the study were the students enrolled in the first semester of the Master of Science in Business Administration program taught in the subject of Techniques and Models for Decision Making in the remote mode of teaching established by the COVID-19 pandemic with a total of 35 . These participants have been selected through convenience sampling. The main characteristics of the sample are: The age range is between 25 and 38 years. With regard to sex, $64 \%$ correspond to women and $36 \%$ to men. Work experience ranges from 1 to 15 years. $92 \%$ work in the private sector and $8 \%$ in the public sector. Regarding the time of use of the technology, $70 \%$ allocate 6 to 10 hours and $30 \% 1$ to 5 hours.

\subsection{Didactic Intervention}

The stages of the PBL are presented in Table 1.

Table 1. Stages of PBL

\begin{tabular}{|c|c|}
\hline $\begin{array}{c}\text { FIRST STAGE: } \\
\text { Project theme }\end{array}$ & ACTIVITIES \\
\hline $\begin{array}{l}\text { First session online } \\
\text { by Zoom } \\
\text { (synchronous) }\end{array}$ & $\begin{array}{l}\text { The objective, competences to be } \\
\text { developed, contents and evaluation } \\
\text { of the subject were presented to the } \\
\text { students. } \\
\text { Teacher explanation about the } \\
\text { didactic methodology to be used. } \\
\text { The digital teaching resources to be } \\
\text { used (videos, articles and } \\
\text { presentations) were explained. } \\
\text { Assembly with the student body for } \\
\text { the election and delimitation of the } \\
\text { subject, highlighting that it is } \\
\text { related to their graduate degree in } \\
\text { administration. }\end{array}$ \\
\hline $\begin{array}{l}\text { Second session } \\
\text { (synchronous) }\end{array}$ & $\begin{array}{l}\text { The topics to be developed: Effects } \\
\text { of the COVID- } 19 \text { pandemic in the } \\
\text { business sector from a quantitative } \\
\text { model. }\end{array}$ \\
\hline
\end{tabular}

\section{SECOND STAGE:}

Search and

selection of

information

\section{ACTIVITIES}

\begin{tabular}{ll}
\hline & $\begin{array}{l}\text { Teams were organized to develop } \\
\text { the theoretical and contextual }\end{array}$ \\
framework, establishing as criteria: & topicality and significance for the \\
magazine articles & $\begin{array}{l}\text { administrative field. } \\
\text { and books } \\
\text { (asynchronous) }\end{array}$ \\
& $\begin{array}{l}\text { During this process, the teaching } \\
\text { staff carried out a review of } \\
\text { progress indicating areas for } \\
\text { improvement. }\end{array}$ \\
\hline
\end{tabular}




\begin{tabular}{|c|c|}
\hline $\begin{array}{l}\text { THIRD STAGE: } \\
\text { Socialization }\end{array}$ & ACTIVITIES \\
\hline $\begin{array}{l}\text { Online sessions by } \\
\text { Zoom } \\
\text { (synchronous) }\end{array}$ & $\begin{array}{l}\text { Advances before the group: } \\
\text { mention the study variables and } \\
\text { estimated model. } \\
\text { Each synchronous session is } \\
\text { concluded with a socialization } \\
\text { space on the relevance and } \\
\text { usefulness in professional training } \\
\text { where the teacher is the mediator. }\end{array}$ \\
\hline FOURTH STAGE & ACTIVITIES \\
\hline $\begin{array}{l}\text { Report } \\
\text { (asynchronous) }\end{array}$ & $\begin{array}{l}\text { Preparation of the report that } \\
\text { includes the statement of the } \\
\text { problem, the formulation of the } \\
\text { model, estimation and } \\
\text { interpretation of results. } \\
\text { The conclusions and proposed } \\
\text { solution were established. }\end{array}$ \\
\hline FIFTH STAGE & ACTIVITIES \\
\hline $\begin{array}{l}\text { Online project } \\
\text { presentation by } \\
\text { Zoom } \\
\text { (synchronous) }\end{array}$ & $\begin{array}{l}\text { Each team presented its final model } \\
\text { indicating its scope and decision- } \\
\text { making for the administrative field. }\end{array}$ \\
\hline $\begin{array}{l}\text { Online Course } \\
\text { Evaluation by } \\
\text { Zoom } \\
\text { (Synchronous) }\end{array}$ & $\begin{array}{l}\text { The students did it to express the } \\
\text { comments of the course and their } \\
\text { experience using the PBL } \\
\text { methodology. } \\
\text { The research instrument was } \\
\text { implemented. }\end{array}$ \\
\hline
\end{tabular}

Source: Own elaboration

\subsection{Instrument}

The data were collected through a questionnaire organized by 1) Socio-labour data; 2) Training of competences provided by the PBL in the categories of mathematical and soft type and, 3) Assessment of the didactic experience of the PBL. The responses are configured on a five-point Likert scale, ranging from (1) totally disagree to (5) totally agree. The content validity was performed through the judgment of experts made up of five researchers with experience in education. Reliability was carried out through Cronbach's alpha coefficient with a value of 0.905, making it acceptable [44]. The Kaiser-MeyerOlkin test was relevant $(\mathrm{KMO}=0.833)$, and the Bartlett sphericity test was adequate $\left(X^{2}=3154.88\right.$; $\mathrm{p}<0.001)$, so it is an empirically validated instrument through exploratory factor analysis.

\subsection{Procedure and Data Analysis}

The application of the instrument was carried out once the course had concluded, indicating to the participants the objective and relevance of the study, as well as establishing the confidentiality of the information for the students who voluntarily agreed to participate. The researcher distributed the instrument digitally via email. The statistical study was carried out using the SPSS version 25 program, which allowed the organization of the data through descriptive statistics: mean (M) and standard deviation (SD).

\section{Results}

The first findings of the study correspond to the training of mathematical competences developed through PBL, which are shown in Table 2.

Table 2. Descriptive statistics of mathematical training

\begin{tabular}{lcc}
\multirow{2}{*}{$\begin{array}{l}\text { The PBL developed the mathematical } \\
\text { competence of }\end{array}$} & \multicolumn{2}{c}{ Statistics } \\
\cline { 2 - 3 } & $\mathrm{M}$ & $\mathrm{SD}$ \\
\hline Use mathematical terminology & 4.95 & 0.11 \\
Recognize the types of quantitative & 4.23 & 0.35 \\
models & 4.35 & 0.42 \\
Identify the variables & 4.69 & 0.15 \\
Formulate the quantitative model & 4.67 & 0.18 \\
$\begin{array}{l}\text { Estimate the quantitative model } \\
\text { Use ICTs for the development and }\end{array}$ & 4.72 & 0.14 \\
$\begin{array}{l}\text { presentation of the model } \\
\text { Mathematically argue the constructed } \\
\text { model }\end{array}$ & 4.13 & 0.36 \\
$\begin{array}{l}\text { Interpret the results of the model } \\
\text { Determine administrative decision- } \\
\text { making based on the model }\end{array}$ & 4.37 & 0.26 \\
\hline
\end{tabular}

Source: Own elaboration

From Table 2., it was found that the effectiveness of PBL from the perception of the students allowed the development of the mathematical competences established in the graduate course, highlighting with the highest mean score: Using mathematical terminology $(\mathrm{M}=4.95, \mathrm{SD}=0.11)$; use ICT for the development and presentation of the model $(\mathrm{M}=$ $4.72, \mathrm{SD}=0.14)$; formulate the quantitative model $(\mathrm{M}=4.69, \mathrm{SD}=0.15)$ and estimate the model $(\mathrm{M}=$ 4.67, $\mathrm{SD}=0.18$ ). These results show that students have a command of these mathematical competences: formulation and estimation of quantitative models with the support of ICT, using the respective terminology. These technical skills will allow students to position themselves in the organization where they work today or to access a better job position in the future. Regarding the training of the soft skills developed through PBL, they are presented in Table 3.

Table 3. Descriptive statistics on the development of soft skills

\begin{tabular}{lcc}
\hline \multirow{2}{*}{ The PBL developed the ability to } & \multicolumn{2}{c}{ Statistics } \\
\cline { 2 - 3 } & Mean & SD \\
\hline Verbal communication & 4.42 & 0.69 \\
\hline Written communication & 4.55 & 0.57 \\
\hline Collaborative work & 4.88 & 0.32 \\
\hline Adaptability & 4.75 & 0.39 \\
\hline Self-knowledge & 4.65 & 0.46 \\
\hline
\end{tabular}




\begin{tabular}{lll}
\hline Decision making & 4.83 & 0.28 \\
\hline Time management & 4.91 & 0.21 \\
\hline Self-regulation & 4.87 & 0.25 \\
\hline
\end{tabular}

Source: Own elaboration

In the same way, the findings on the development of soft skills in graduate level students during confinement indicate a consolidated training because the participants' assessments are higher than four points on average, which is why stand out in descending order the time management $(\mathrm{M}=4.91$, $\mathrm{SD}=0.21)$, collaborative work $(\mathrm{M}=4.88, \mathrm{SD}=$ $0.32)$, self-regulation $(\mathrm{M}=4.87, \mathrm{SD}=0.25)$, decision making $(\mathrm{M}=4.83, \mathrm{SD}=0.28)$, adaptability $(\mathrm{M}=$ $4.75, \mathrm{SD}=0.39)$, self-knowledge $(\mathrm{M}=4.65, \mathrm{SD}=$ $0.46)$, written communication $(\mathrm{M}=4.55, \mathrm{SD}=0.57)$ and verbal communication $(\mathrm{M}=4.42, \mathrm{SD}=0.69)$. These results allow deducing the effectiveness of the PBL methodology to develop soft skills because they are an important component of a comprehensive training. This level of development of soft skills in students also enables better job performance due to the uncertain environment in which organizations find themselves.

Table 4. Descriptive statistics on the assessment of the didactic experience

\begin{tabular}{lcc}
\hline \multirow{2}{*}{ The PBL allowed } & \multicolumn{2}{c}{ Statistics } \\
\cline { 2 - 3 } & Mean & SD \\
\hline Learning was dynamic & 4.56 & 0.59 \\
\hline Professional training was experiential & 4.77 & 0.37 \\
\hline $\begin{array}{l}\text { Synchronous classes using Zoom were } \\
\text { interesting }\end{array}$ & 4.62 & 0.41 \\
\hline $\begin{array}{l}\text { The feedback from the teaching staff } \\
\text { was timely }\end{array}$ & 4.52 & 0.62 \\
\hline $\begin{array}{l}\text { The motivation was permanent during } \\
\text { the course }\end{array}$ & 4.53 & 0.61 \\
\hline $\begin{array}{l}\text { The academic training is of quality } \\
\text { The online mode was enjoyed }\end{array}$ & 4.93 & 0.17 \\
\hline
\end{tabular}

Source: Own elaboration

Table 4. shows the findings regarding the assessment of the didactic experience provided by PBL, which was perceived favourably by the students. The results show that PBL generates quality academic training $(\mathrm{M}=4.93, \mathrm{SD}=0.17)$ as well as experiential $(\mathrm{M}=4.77, \mathrm{SD}=0.37)$. Also, the students recognize that $\mathrm{PBL}$ allows synchronous classes to be interesting $(\mathrm{M}=4.62, \mathrm{SD}=0.41)$, dynamic learning $(\mathrm{M}=4.56, \quad \mathrm{SD}=0.59)$, continuous motivation throughout the course $(\mathrm{M}=4.53, \mathrm{SD}=0.61)$, as well as that the teachers provide timely feedback on the development of the project $(\mathrm{M}=4.52, \mathrm{SD}=0.62)$. However, not all students enjoy learning in the virtual mode $(\mathrm{M}=3.96, \mathrm{SD}=0.89)$.

\section{Discussion and Conclusion}

The emergence of COVID-19 has generated new scenarios for professional training at the graduate level where the diversified use of ICT has been positioned as a central element to continue with academic continuity during confinement. Thus, in the context of the coronavirus, the general objective of the research has been achieved regarding the use of the PBL methodology for the development of both mathematical competences and soft skills based on the favourable assessment made by the students. In this sense, the research provides useful information for the graduate level regarding professional training, as mentioned by [22].

In this way, education is facing the main challenge related to the transformation of the face-to-face classroom to a virtual or hybrid classroom, which is why [19], [20] coincide. What was established by Esteban-Guitart et al. [11] regarding the importance of using technological tools to connect learning practices with experiences related to the workplace is also confirmed. In addition, PBL allows the interrelation of the course contents with real learning experiences, thus promoting quality professional training at the graduate level, as stated by [27], [39]. Also, for the graduate level, the PBL encourages the research process through the development of the project with a current topic, which is confirmed by what is reported by [34], [37]. On the contrary, this research differs from what indicated Díaz-Barriga and Barrón [21] regarding the little significant experiences in the training of students during confinement. Therefore, this study is in complete agreement with Berry and Routon [6]; Tseng et al. [8] on the importance of merging technical and soft skills because they increase the chances of having a better job position.

This research contributes to knowledge by having a first approach about the importance of incorporating active methodologies at the graduate level such as PBL with technological support and the use of synchronous sessions through Zoom that allow providing quality academic training for a course of mathematics, which is why it coincides with what Echeita [23], Allen et al. [24] state regarding the possibility of using PBL in the hybrid modality. Nonetheless, the main limitation of the study is related to the generalization of the results as they are oriented to a single subject. It is recommended to extend the use of PBL to other graduate subjects to carry out the assessment of its effectiveness in the professional training of graduate students. It is even suggested to explore in other graduate programs, in other areas of knowledge, or in other educational institutions. In relation to the prospective that is also derived from this study, the opportunity to investigate the characteristics of the formative assessment used in the context of the COVID-19 pandemic is mentioned. 


\section{Acknowledgements}

This research was supported by the Instituto Politécnico Nacional, Mexico [SIP number 20210598 entitled "Educational leadership for sustainable organizational development in the new normal”].

\section{References}

[1]. Tang, T., Abuhmaid, A. M., Olaimat, M., Oudat, D. M., Aldhaeebi, M., \& Bamanger, E. (2020). Efficiency of flipped classroom with online-based teaching under COVID-19. Interactive Learning Environments, 1-12. https://doi.org/10.1080/10494820.2020.1817761

[2]. Jurado de los Santos, P., Moreno-Guerrero, A. J., Marín-Marín, J. A., \& Soler Costa, R. (2020). The term equity in education: A literature review with scientific mapping in Web of Science. International Journal of Environmental Research and Public Health, 17(10), 3526. https://doi.org/10.3390/ijerph17103526

[3]. Moncada, B. S., \& Prado, J. M. L. (2021). Implementación de la educación virtual en tiempos de COVID-19 en la Facultad de Música de la UANL. RIDE Revista Iberoamericana para la Investigación y el Desarrollo Educativo, 12(23). https://doi.org/10.23913/ride.v12i23.995

[4]. Sargent, J., \& Casey, A. (2020). Flipped learning, pedagogy and digital technology: Establishing consistent practice to optimise lesson time. European physical education review, 26(1), 70-84.

https://doi.org/10.1177/1356336x1982660

[5]. Peters, M. A. (2017). Technological Unemployment: Educating For The Fourth Industrial Revolution. Journal of Self-Governance and Management Economics, 5(1), 25-33. https://doi.org/10.1080/00131857.2016.1177412

[6]. Berry, R., \& Routon, W. (2020). Soft skill change perceptions of accounting majors: Current practitioner views versus their own reality. Journal of Accounting Education, 53, 100691. https://doi.org/10.1016/j.jaccedu.2020.100691

[7]. González, J. A. R., Granados, I. N., Clavijo, S. L. L., \& Ruiz, G. M. G. (2021). Habilidades blandas en el contexto universitario y laboral. Inclusión y Desarrollo, 8(2), 113-127. https://doi.org/10.26620/uniminuto.inclusion.8.2.2021 $.113-127$

[8]. Tseng, H., Yi, X., \& Yeh, H. T. (2019). Learningrelated soft skills among online business students in higher education: Grade level and managerial role differences in self-regulation, motivation, and social skill. Computers in Human Behavior, 95, 179-186. https://doi.org/10.1016/j.chb.2018.11.035

[9]. Organisation for Economic Co-operation and Development. (2015). Skills for social progress: The power of social and emotional skills. OECD Publishing. https://doi.org/10.1787/9789264226159-en
[10]. World Economic Forum (WEF, 2020). Estas son las 10 principales habilidades laborales del futuro y el tiempo que lleva aprenderlas. Retrieved from: https://es.weforum.org/agenda/2020/10/estas-son-las10 -principales-habilidades-laborales-del-futuro-y-eltiempo-que-lleva-aprenderlas/ [accessed: 10 June 2021].

[11]. Esteban-Guitart, M., Monreal-Bosch, P., Palma, M., \& González-Ceballos, I. (2020). Sustaining students' identities within the context of participatory culture. Designing, implementing and evaluating an interactive learning activity. Sustainability, 12(12), 4870. $\quad$ https://doi.org/10.3390/su12124870

[12]. Rego-Agraso, L. (2018). Los centros de formación profesional y su vinculación con el entorno: la perspectiva de alumnado y profesorado. Revista complutense de educación, 29(3), 683-697. http://dx.doi.org/10.5209/RCED.53622

[13]. Vergel-Ortega, M., Duarte, H. I., \& MartínezLozano, J. J. (2015). Desarrollo del pensamiento matemático en estudiantes de cálculo integral su relación con la planificación docente. Revista científica, 3(23), 17-29.

https://doi.org/10.14483/udistrital.jour.RC.2015.23.a2

[14]. Chaves, C. (2016). Habilidades del siglo XXI. Revista Conexiones, 8(2), 12-18.

[15]. De Villiers, R. (2010). The incorporation of soft skills into accounting curricula: preparing accounting graduates for their unpredictable futures. Meditari: Research Journal of the School of Accounting Sciences, 18(2), 1-22. https://doi.org/10.1108/10222529201000007

[16]. Cárdenas, A. M. H. C., \& Inacio, E. J. H. (2018). Desarrollo de habilidades sociales en contextos universitarios. Horizonte de la Ciencia, 8(14), 123130.

[17]. Franco, H. M., Zambrano, C. R. A., \& Ramírez, V. V. C. (2017). El cálculo diferencial: aplicación en la microeconomía bancaria. Olimpia: Publicación científica de la facultad de cultura física de la Universidad de Granma, 14(46), 55-69.

[18]. Zhang, A. (2012). Peer assessment of soft skills and hard skills. Journal of Information Technology Education: Research, 11(1), 155-168. https://doi.org/10.28945/1634

[19]. González-Patiño, J., \& Esteban-Guitart, M. (2021). La transformación hacia experiencias expandidas en educación superior: curso\# UAMskills de identidad digital. Revista de Educación a Distancia (RED), 21(65). https://doi.org/10.6018/red.433881

[20]. Bozkurt, A., \& Sharma, R. C. (2020). Emergency remote teaching in a time of global crisis due to CoronaVirus pandemic. Asian Journal of Distance Education, 15(1). https://doi.org/10.5281/zenodo.3778083

[21]. Barriga, F. D., \& Tirado, C. B. (2020). Currículo y pandemia: Tiempo de crisis y oportunidad de disrupción. Revista Electrónica Educare, 24, 4. https://doi.org/10.15359/ree.24-S.3 
[22]. Mendiola, M. S., Hernández, A., Torres, R., Carrasco, M. D. A. S., Romo, A. K. H., Mario, A., \& Cazales, V. (2020). Retos educativos durante la pandemia de COVID-19: una encuesta a profesores de la UNAM. Revista digital universitaria, 21(3), 1-24.

[23]. Echeita, G. (2020). La pandemia del Covid-19.i Una oportunidad para pensar en cómo hacer más inclusivos nuestros sistemas educativos. Revista Internacional de Educación para la Justicia Social, 9(1), 7-16.

[24]. Allen, J., Rowan, L. \& Singh, P. (2020). Teaching and teacher education in the time of COVID-19. AsiaPacific Journal of Teacher Education, 48(3), 233-236. https://doi.org/10.1080/1359866X.2020.1752051

[25]. García, A. E., García, J. E., \& Rubio, P. V. (2020). Reflexiones pedagógicas en época de pandemia: Un abordaje transdisciplinar. RECUS. Revista Electrónica Cooperación Universidad Sociedad. ISSN 25288075, 5(2),

$7-12$. https://doi.org/10.33936/recus.v5i2.2535

[26]. Rodríguez-Sandoval, E., Vargas-Solano, É. M., \& Luna-Cortés, J. (2010). Evaluación de la estrategia" aprendizaje basado en proyectos". Educación $y$ educadores, 13(1), 13-25.

[27]. Alptekin, S. E., DeTurris, D., Macy, D. J., \& Ervin, J. E. (2005). Development of a flying eye: A projectbased learning experience. Journal of Manufacturing Systems, 24(3), 226-236. https://doi.org/10.1016/S0278-6125(06)80012-9

[28]. Nawi, N. D., Phang, F. A., Mohd-Yusof, K., Rahman, N. F. A., Zakaria, Z. Y., bin Syed Hassan, S. A. H., \& Musa, A. N. (2019). Instilling Low Carbon Awareness through Technology-Enhanced Cooperative Problem Based Learning. International Journal of Emerging Technologies in Learning, 14(24), 152-166. https://doi.org/10.3991/ijet.v14i24.12135

[29]. Roig-Vila, R., \& Herrero, J. F. Á. (2019). Repercusión en Twitter de las metodologías activas ABP, Flipped Classroom y Gamificación. Revista Iberoamericana de Educación a Distancia, 22(2), 7996. http://dx.doi.org/10.5944/ried.22.2.23272

[30]. Díaz, M. J. S., \& Martín, R. P. (2018). Flipped classroom para adquirir la competencia digital docente: Una experiencia didáctica en la Educación Superior. Pixel-Bit: Revista de medios y educación, (52), 37-54.

http://dx.doi.org/10.12795/pixelbit.2018.i52.03

[31]. Landron, M. L., Montoro, M. A., \& Ruiz, M. J. C. (2018). El efecto del aprendizaje basado en proyectos en estudiantes con altas capacidades intelectuales de una segunda lengua The effect of project-based learning in gifted students of a second language. Revista de educación, 380, 210-236. http://hdl.handle.net/11162/157391

[32]. Ramón, P. R., Redondo, R. F., Gundín, O. A., \& Fernández, L. Á. (2015). Percepción de los estudiantes sobre el desarrollo de competencias a través de diferentes metodologías activas. Revista de Investigación Educativa, 33(2), 369-383. http://dx.doi.org/10.6018/rie.33.2.201381
[33]. Suarez, A. Á., García, J. A. G., Álvarez, J. A., \& Pérez, J. L. A. (2014). Indicadores centinela para el plan de Bolonia. Revista de Investigación Educativa, 32(2), 327-338.

[34]. Mateos Naranjo, E., Redondo Gómez, S., Serrano Martín, L., Delibes Mateos, M., \& Zunzunegui González, M. (2020). Implantación de una metodología docente activa en la asignatura de Redacción y Ejecución de Proyectos del Grado en Biología. Revista de estudios y experiencias en educación, 19(39), 259-274.

[35]. Soria, I. N., Gómez, C. G., Monsalve, B. L., \& Fontanillo, A. C. (2019). Aprendizaje cooperativo basado en proyectos y entornos virtuales para la formación de futuros maestros. Educar, 55(2), 519541. $\quad$ https://doi.org/10.5565/rev/educar.935

[36]. Pascagaza, E. F., \& Bohórquez, B. G. (2019). El Aprendizaje Basado en Proyectos y su relación con el desarrollo de competencias asociadas al trabajo colaborativo. Amauta, 17(33), 103-118. http://dx.doi.org/10.15648/am.33.2019.8

[37]. Castro, J. P. (2017). Educación emprendedora y metodologías activas para su fomento. Revista electrónica interuniversitaria de formación del profesorado, 20(3), 33-48.

[38]. Thomas, J. W. (2010). A review of research on project-based learning. 2000. The Autodesk Foundation: San Rafael.

[39]. Hernández, J. M., Reyes, A., Dueñas, J. A., Merchán, M. M., \& López, G. D. (2021). ProjectBased Learning as a Pedagogical Tool in Teaching the Safe Management of Pesticides in an AgriculturalRural Community. REMIE: Multidisciplinary Journal of Educational Research, 11(2), 128-151. https://doi.org/10.17583/remie.6794

[40]. Sakulviriyakitkul, P., Sintanakul, K., \& Srisomphan, J. (2020). The design of a learning process for promoting teamwork using project-based learning and the concept of agile software development. International Journal of Emerging Technologies in Learning (IJET), 15(3), 207-222. http://doi.org/10.3991/ijet.v15i03.10480

[41]. Holguín, V. M. G., Tavera, J. A. F., \& López, A. M. B. (2018). Desarrollo de habilidades blandas y el uso del Sistema de Gestión del Aprendizaje en la elaboración de proyectos prácticos en una asignatura introductoria de Ingeniería Telemática. Cuaderno de Pedagogía Universitaria, 15(29), 44-53.

[42]. Hernández-Sampieri, R., \& Mendoza, C. (2018). Metodología de la investigación. Las rutas cuantitativa, cualitativa y mixta. México. McGrawHill.

[43]. García-Valcárcel, A. (2015). Investigación educativa centrada en estudio de casos: evaluación y seguimiento de proyectos de aprendizaje colaborativo mediado por TIC en el ámbito escolar. Proyectos de trabajo colaborativo con TIC, 31-41.

[44]. González Alonso, J., \& Pazmiño Santacruz, M. (2015). Cálculo e interpretación del Alfa de Cronbach para el caso de validación de la consistencia interna de un cuestionario, con dos posibles escalas tipo Likert. Revista publicando, 2(1), 62-67. 